\title{
PENGARUH PEMBERIAN INFUSA BATANG GELAGAH (Saccharum spontaneum L.) TERHADAP KADAR GLUKOSA DARAH MENCIT PUTIH (Mus musculus L.) JANTAN YANG DIINDUKSI GLUKOSA
}

\author{
Mira Febrina $^{1 *}$, Nurhariyati ${ }^{1}$

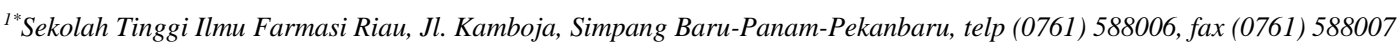

e-mail: mirafebrina@stifar-riau.ac.id

\begin{abstract}
ABSTRAK
Telah dilakukan penelitian tentang pengaruh infusa batang gelagah (Saccharum spontaneum L.) terhadap kadar glukosa darah mencit putih (Mus musculus L.) jantan yang diinduksi glukosa. Penelitian ini bertujuan untuk melihat pengaruh infusa batang gelagah (Saccharum spontaneum L.) terhadap kadar glukosa darah mencit putih (Mus musculus $\mathrm{L}$.) jantan yang diinduksi glukosa $2 \mathrm{~g} / \mathrm{KgBB}$. Penelitian ini menggunakan metode Tes Toleransi Glukosa Oral (TTGO). Hewan percobaan dibagi menjadi 6 kelompok. Kelompok kontrol negatif hanya diberikan akuades, kelompok kontrol pembanding hanya diberikan larutan glukosa $2 \mathrm{~g} / \mathrm{KgBB}$, kelompok positif diberi Metfromin dengan dosis $65 \mathrm{mg} / \mathrm{KgBB}$, kelompok perlakuan diberi sediaan infusa batang gelagah (Saccharum spontaneum L.) dengan konsentrasi 10\%, 20\% dan 30\%. Setelah masing-masing hewan uji diberi perlakuan 30 menit kemudian diberi glukosa 2g/KgBB secara oral. Kemudian dilakukan pengukuran kadar glukosa darah mencit pada menit 30-180. Berdasarkan hasil pengujian infusa batang gelagah (Saccharum spontaneum L.) menunjukkan bahwa konsentrasi $10 \%$, 20\% dan $30 \%$ memiliki penurunan kadar glukosa darah mencit putih (Mus musculus L). Hasil yang diperoleh dari hasil uji ANOVA dua arah dilanjutkan dengan uji Post Hoc Tukey juga menunjukkan bahwa lama pemberian dapat mempengaruhi penurunan kadar glukosa darah mencit $(\mathrm{p}<0,05)$.
\end{abstract}

Kata kunci : infusa batang gelagah, metformin, glukosa, Tes Toleransi Glukosa Oral (TTGO)

\begin{abstract}
A study on the effect of reeds infusion (Saccharum spontaneum L.) on glucose levels of male white mice (Mus musculus) given glucose load. This study aims to see the effect of reeds infusion (Saccharum spontaneum L.) to blood glucose levels of male white mice (Mus musculus) given glucose load as much as $2 \mathrm{~g} / \mathrm{KgBB}$. This research used Oral Glucose Tolerance Test (TTGO) method. Animal experiments were divided into 6 groups. The negative control group was given only aquadest, the comparison group was given $2 \mathrm{~g} / \mathrm{KgBB}$ glucose solution, the positive group was given metformin with the dosage of $65 \mathrm{mg} / \mathrm{KgBB}$, the treatment group was given reeds infusion (Saccharum spontaneum L.) with concentration 10, 20 and $30 \%$. After each test animal was given 30 minutes treatment then given glucose $2 \mathrm{~g} / \mathrm{KgBB}$ orally. Then measured blood glucose levels of mice at minute $30-180$. Based on the results of testing the infusion of reeds (Saccharum spontaneum L..) showed that the concentrations of 10, 20 and $30 \%$ had decreased levels of white mice blood glucose (Mus musculus L.). However, the results of the two way ANOVA assay continued with the Post Hoc Tukey test showed the results obtained that the duration of administration may affect the decrease in blood glucose levels of mice $(\mathrm{p}<0.05)$.
\end{abstract}

Keywords : reeds infusion, metformin, glucose, Oral Glucose Tolerance Test (TTGO)

PENDAHULUAN

Diabetes melitus (DM) adalah gangguan metabolisme yang ditandai dengan hiperglikemia. Hal ini berkaitan dengan kelainan metabolisme karbohidrat, lemak, dan protein yang dapat menyebabkan komplikasi kronis termasuk gangguan mikrovaskuler, makrovaskuler dan neuropatik (Dipiro et al., 2015).

Badan Kesehatan Dunia World Health Organization (WHO) mengatakan bahwa jumlah penyandang DM di Indonesia mengalami peningkatan jumlah penyandang sebanyak 2-3 kali lipat, Sedangkan menurut International Diabetes Federation (IDF) kenaikan jumlah penyandang DM di Indonesia dari tahun 2014 yang berjumlah 9,1 juta jiwa diprediksikan menjadi 14,1 juta jiwa pada tahun 2035 (Perkeni, 2015). Berdasarkan data Riskesdas tahun 2018 dilaporkan bahwa prevalensi DM lebih tinggi sebanyak 2,1\% dibandingkan pada tahun 2007 yaitu sebanyak $1,1 \%$. Hal ini kemungkinan diakibatkan oleh pola hidup yang tidak sehat (Kemenkes RI, 2018).

Untuk menurunkan kejadian dan keparahan dari Diabetes Melitus maka dilakukan pencegahan seperti modifikasi gaya hidup dan pengobatan seperti obat hipoglikemia oral dan insulin (Depkes RI, 2005).

Penggunaan obat hipoglikemia oral merupakan pilihan utama dalam menangani penyakit diabetes melitus. Penggunaan obat hipoglikemia oral ini biasanya berlangsung lama dengan efek samping yang ditimbulkan cukup besar, sehingga biaya yang dikeluarkan penderita secara keseluruhan cukup besar. Maka diperlukan suatu alternatif pengobatan yaitu penggunaan obat tradisional dari bahan alam. Obat tradisional sejak dahulu telah digunakan oleh masyarakat secara luas dalam upaya meningkatkan pelayanan kesehatan untuk mengobati berbagai penyakit. Agar peranan obat tradisional khususnya tumbuhan berkhasiat obat dalam pelayanan kesehatan dapat lebih ditingkatkan, maka perlu dilakukan upaya berupa pengenalan, pengujian, penelitian dan pengembangan obat tradisonal yang ternyata berhasil dan berdayaguna serta dapat diterima oleh masyarakat (Wijayakusuma, 1995).

Salah satu tumbuhan yang berkhasiat obat yang dikenal oleh masyarakat dan digunakan sebagai obat tradisional yaitu batang gelagah (Saccharum 
spontaneum L.). Tumbuhan gelagah memiliki banyak manfaat mulai dari akar, batang hingga daunnya. Menurut Khalid \& Siddiqui, (2011) secara empiris tumbuhan ini banyak digunakan oleh masyarakat India sebagai obat tradisional diantaranya digunakan sebagai obat wasir, dyspepsia, ginjal dan paru-paru, sedangkan tunas muda dan daun gelagah digunakan untuk pengobatan diabetes melitus (Tag et al., 2012). Di Kalimantan Timur masyarakat menggunakan bagian dalam batang gelagah yang masih muda sebagai obat diabetes dengan meminum air rebusan batang tersebut (Norcahyati, 2012). Secara ilmiah tumbuhan ini juga sudah banyak diteliti manfaatnya. Menurut Ripa et al., (2009) ekstrak kloroform bunga gelagah merupakan sumber antioksidan alami yang baik serta memiliki efek antimikroba dan efek sitotoksik. Sedangkan menurut penelitian Lapuz et al., (2016) ekstrak etanol akar gelagah memiliki potensi antiinflamasi yang setara dengan gel Natrium diklofenak $1 \%$.

Di Indonesia khususnya masyarakat desa Sungai Kumango, Rokan Hulu, Riau banyak menggunakan batang gelagah sebagai obat tradisional untuk mengobati penyakit diabetes melitus, dengan cara merebus satu ruas batang gelagah dengan dua gelas air yang setara dengan $500 \mathrm{~mL}$ dijadikan satu gelas.

Berdasarkan hasil uji pendahuluan fitokimia yang dilaporkan oleh Devi \& Muthu, (2014) diketahui bahwa ekstrak tumbuhan gelagah yang didapat dari Tamil Nadu, India positif mengandung senyawa dari golongan alkaloid, flavonoid, fenolik, saponin, tanin, terpenoid dan senyawa metabolit lainnya. Berdasarkan uji fitokimia yang dilaporkan oleh Hidayatullah \& Mora, (2018), diketahui bahwa ekstrak etanol tumbuhan batang gelagah yang didapat dari desa Rokan IV Koto,Rokan Hulu, Riau positif mengandung senyawa golongan alkaloid, steroid dan flavonoid.

Flavonoid memiliki kemampuan untuk meregenerasi dan merangsang pelepasan insulin pada sel $\beta$ pankreas dan juga mampu mengurangi penyerapan glukosa, mengatur aktivitas enzim yang terlibat dalam metabolisme karbohidrat dan menghambat penguraian polisakarida menjadi monosakarida sehingga tanaman dan buah-buahan yang mengandung flavonoid sering digunakan sebagai obat penurun kadar glukosa darah. (Dheer \& Bhatnagar, 2010).

Pengukuran kadar glukosa darah bisa menggunakan berbagai cara diantaranya dengan glukosa darah sewaktu, glukosa darah puasa dan Tes Toleransi Glukosa Oral (TTGO) (Perkeni, 2015). TTGO memiliki kelebihan yaitu dapat menyimpulkan suatu data mengenai resiko seseorang dapat menderita penyakit diabetes atau sudah menderita diabetes melitus. Metode ini juga dapat menyebabkan kenaikan glukosa darah dengan cepat setelah penginduksian glukosa secara oral (American Diabetes Association, 2014).

Berdasarkan uraian diatas maka peneliti tertarik untuk menguji apakah infusa batang gelagah (Saccharum spontaneum L.) dapat menurunkan kadar glukosa darah mencit putih jantan (Mus musculus L.) yang diinduksi glukosa dengan menggunakan metoda TTGO (Tes Toleransi Glukosa Oral).

\section{METODOLOGI}

\section{Alat dan Bahan}

Alat yang digunakan pada penelitian ini adalah panci infusa, kompor gas, termometer raksa, corong, gelas ukur, cawan penguap , beker gelas, kain flanel, plat tetes, penjepit buaya, api bunsen, batang pengaduk, lumpang dan alu, gunting, timbangan hewan, timbangan analitik, pipet tetes, kandang pemeliharan hewan uji, kandang metabolit, timbangan hewan, alat suntik, sonde oral, tabung reaksi, kapas, stopwatch, handscoon, syringe, vial, masker, alat pengukur kadar gula darah (glukometer) dan strips test (Multicheck $\left.\operatorname{Nesco}^{\circledR}\right)$.

Bahan yang digunakan pada penelitian ini yaitu kloroform, kloroform:amoniak $0,05 \mathrm{~N}$, asam sulfat $2 \mathrm{~N}$, $\mathrm{HCl} 2 \%$, pereaksi Mayer, logam $\mathrm{Mg}, \mathrm{HCl}$ pekat, metanol panas, ferri klorida $1 \%$, akuades, $\mathrm{HCl} 1 \mathrm{~N}$, asam asetat anhidrat, asam sulfat pekat, glukosa dan metformin tablet (PT. Bernofarm).

\section{Pengambilan sampel batang gelagah}

Sampel batang gelagah (Saccharum spontaneum L.) yang akan diambil ialah batang gelagah yang masih muda, berwarna hijau, memiliki ukuran tinggi tidak lebih dari 2 meter. Gelagah didapatkan dari tepi sungai Batang Sosah yang ada di Desa Sungai Kumango, Kecamatan Tambusai, Kabupaten Rokan Hulu, Provinsi Riau.

\section{Identifikasi batang gelagah}

Sampel tumbuhan gelagah dalam keadaan lengkap diidentifikasi di Laboratorium Botani jurusan Biologi Fakultas Matematika dan Ilmu Pengetahuan Alam (FMIPA) Universitas Riau, Pekanbaru.

\section{Skrining fitokimia}

Metode analisis yang digunakan berdasarkan pada Harborne (1987).

1. Skrining fitokimia batang gelagah

a. Uji alkaloid

Batang gelagah yang segar dirajang kecil-kecil, lalu digerus dalam lumpang dengan bantuan pasir bersih, ditambahkan $5 \mathrm{~mL}$ kloroform dan $5 \mathrm{~mL}$ kloroform amoniak $0,05 \mathrm{~N}$, digerus dengan perlahan, kemudian saring larutan dengan meletakkan kertas saring/kapas di dalam lumpang, masukkan hasil saringan ke dalam tabung reaksi. Tambahkan 10 tetes asam sulfat 2 $\mathrm{N}$ kocok selama 1 menit. Biarkan sampai terjadi pemisahan. Setelah itu diambil lapisan asam (atas) dan pindahkan ke dalam tabung reaksi lain dan tambahkan beberapa tetes pereaksi Mayer. Reaksi positif ditandai dengan adanya kabut putih. 
b. Uji flavonoid

Beberapa tetes lapisan air diletakkan ke plat tetes, masukkan 1-2 butir logam Mg dan 2 tetes asam klorida pekat. Terbentuk warna jingga, merah muda sampai merah yang menunjukkan adanya flavonoid.

c. Uji fenolik

Beberapa tetes lapisan air diletakkan ke plat tetes dan ditambahkan beberapa tetes larutan ferri klorida $1 \%$, Hasil positif akan membentuk warna hijau hingga biru gelap sampai ungu yang menunjukkan adanya senyawa Fenolik.

d. Uji saponin

Ambil beberapa $\mathrm{mL}$ lapisan air masukkan ke dalam tabung reaksi dikocok kuat, bila terbentuk busa yang tetap selama 5 menit menandakan adanya saponin.

e. Uji terpenoid dan steroid

Lapisan kloroform disaring dengan norit yang diletakkan ke dalam pipet tetes yang diberi kapas ujungnya, kemudian ditampung pada tiga lubang plat tetes, setelah kering pada lubang pertama ditambahkan pereaksi asam asetat anhidrat, lubang kedua ditambahkan asam sulfat pekat dan lubang ketiga ditambahkan asam asetat anhidrat dan asam sulfat pekat sama banyak, bila terbentuk warna merah menunjukkan adanya senyawa terpenoid dan warna biru-ungu atau biru-hijau menunjukkan adanya senyawa steroid.

2. Skrining fitokimia infusa batang gelagah

a. Uji alkaloid

Infusa batang gelagah sebanyak $2 \mathrm{~mL}$ di masukkan kedalam tabung reaksi kemudian ditambahkan dengan 0,5 mL $\mathrm{HCl} 2 \%$. Kemudian tambahkan pereaksi Mayer. Apabila terbentuk kabut putih atau endapan putih terdapat alkaloid.

b. Uji flavonoid

Infusa batang gelagah sebanyak $2 \mathrm{~mL}$ di masukkan kedalam tabung reaksi kemudian ditambahkan $2 \mathrm{~mL}$ metanol panas, kemudian tambahkan logam Mg. Setelah itu tambahkan 4-5 tetes $\mathrm{HCl}$ pekat. Apabila terjadi perubahan warna menjadi merah kekuningan atau jingga, maka sampel positif mengandung Flavonoid.

c. Uji fenolik

Sebanyak $2 \mathrm{~mL}$ infusa daun katuk ditambahkan beberapa tetes larutan besi (III) klorida $1 \%$, terbentukya warna hijau hingga warna biru gelap menandakan adanya fenolik.

d. Uji saponin

Sebanyak $2 \mathrm{~mL}$ infusa batang gelagah di masukkan kedalam tabung reaksi dan tambahkan air (1:1), kemudian kocok kuat-kuat selama 1 menit. Setelah itu tambahkan 2 tetes $\mathrm{HCl} 1 \mathrm{~N}$. Saponin positif jika terbentu busa yang stabil tidak kurang dari 5 menit.

e. Uji terpenoid dan steroid

Sebanyak $2 \mathrm{~mL}$ infusa batang gelagah ditambahkan 0,5 $\mathrm{mL}$ kloroform dan 0,5 $\mathrm{mL}$ asam asetat anhidrat. Setelah itu ditambahkan 2 tetes asam sulfat pekat. Apabila terbentuk warna biru atau biru hijau menunjukkan adanya steroid, sedangkan bila terbentuk cincin kecoklatan menunjukkan adanya terpenoid.

\section{Persiapan hewan percobaan}

Hewan percobaan yang digunakan pada penelitian ini adalah mencit putih (Mus musculus L.) jantan dewasa sebanyak 30 ekor. Umur mencit yang digunakan berkisar antara 2-3 bulan dengan berat antara 20-30 gram.

Sebelum perlakuan hewan percobaan di aklimatisasi selama 7 hari. Mencit di aklimatisasi dalam kondisi laboratorium dengan diberi makanan dan minuman yang cukup. Selama aklimatisasi berat badan ditimbang. Berat badan mencit selama aklimatisasi tidak menunjukkan deviasi bobot badan lebih dari $10 \%$ dan secara visual menunjukkan perilaku yang normal (Ridwan, 2013).

\section{Perencanaan dosis}

Pada penelitian ini konsentrasi infusa batang gelagah yang akan diberikan kepada hewan percobaan yaitu dengan membagi menjadi 3 perlakuan konsentrasi yaitu $10 \%$, 20\% dan 30\%. Volume pemberian secara oral digunakan $1 \%$ dari berat badan hewan. Glukosa yang digunakan adalah glukosa monohidrat dengan konsentrasi $2 \mathrm{~g} / \mathrm{KgBB}$ dengan volume pemberian $1 \% \mathrm{BB}$ mencit. Kelompok kontrol positif diberikan metformin dengan dosis $500 \mathrm{mg}$ jika dikonversikan dari manusia ke mencit $=0,0026 \times 500$ $\mathrm{mg}=1,3 \mathrm{mg} / 20 \mathrm{gBB}$.

\section{Pembuatan infusa batang gelagah}

Infusa dibuat dari batang gelagah $10 \% \mathrm{~b} / \mathrm{v}$ menurut Depkes RI tahun 1995 dengan cara sebagai berikut, batang gelagah dengan berat 10 gram dirajang kecil-kecil, untuk konsentrasi infusa $20 \%$ dan $30 \%$ masing-masing ditimbang 20 dan 30 gram kemudian di masukkan ke dalam panci infusa, ditambahkan akuades hingga $100 \mathrm{~mL}$. Batang gelagah yang telah ditambahkan akuades dipanaskan selama 15 menit terhitung setelah suhu mencapai $90^{\circ} \mathrm{C}$ di dalam panci infusa, sambil sekali-sekali diaduk. Serkai selagi panas menggunakan kain flanel. Jika volume infusa kurang dari $100 \mathrm{~mL}$ dapat ditambahkan dengan air panas yang dilewatkan pada ampas batang gelagah hingga diperoleh $100 \mathrm{~mL}$ infusa batang gelagah.

\section{Pengelompokan hewan percobaan}

Pada penelitian ini hewan percobaan akan dibagi secara acak menjadi 6 kelompok. masingmasing kelompok terdiri dari 5 ekor mencit putih jantan yang selisih berat badannya dalam satu kelompok tidak lebih dari 20\%. Mencit dipuasakan terlebih dahulu selama 18-24 jam, tiap kelompok diberi perlakuan sebagai berikut :

1. Kelompok pertama adalah sebagai kontrol negatif. Mencit putih jantan hanya diberikan larutan akuades. 
2. Kelompok kedua adalah sebagai kontrol pembanding. Mencit putih jantan hanya diberikan larutan glukosa $2 \mathrm{~g} / \mathrm{KgBB}$.

3. Kelompok ketiga adalah sebagai kontrol Positif. Mencit putih jantan diberikan larutan metformin $1,3 \mathrm{mg} / 20 \mathrm{gBB}$ dan 30 menit kemudian diberikan lautan glukosa $2 \mathrm{~g} / \mathrm{KgBB}$.

4. Kelompok keempat sebagai kelompok perlakuan 1 . Mencit putih jantan diberikan infusa batang gelagah secara oral dengan konsentrasi $10 \% \mathrm{~b} / \mathrm{v}$ dengan volume pemberian $1 \%$ dari $\mathrm{BB}$ dan 30 menit kemudian diberikan larutan glukosa $2 \mathrm{~g} / \mathrm{KgBB}$.

5. Kelompok kelima sebagai kelompok perlakuan 2 . Mencit putih jantan diberikan infusa batang gelagah secara oral dengan konsentrasi $20 \% \mathrm{~b} / \mathrm{v}$ dengan volume $1 \%$ dari $\mathrm{BB}$ dan 30 menit kemudian diberikan larutan glukosa $2 \mathrm{~g} / \mathrm{KgBB}$.

6. Kelompok keenam sebagai kelompok Perlakuan 3. Mencit putih jantan diberikan infusa batang gelagah secara oral dengan konsentrasi $30 \% \mathrm{~b} / \mathrm{v}$ dengan volume pemberian $1 \%$ dari $\mathrm{BB}$ dan 30 menit kemudian diberikan larutan glukosa $2 \mathrm{~g} / \mathrm{KgBB}$.

\section{Uji Toleransi Glukosa Oral (TTGO)}

Metode induksi yang digunakan dalam percobaan ini adalah metode Tes Toleransi Glukosa Oral (TTGO) dimana hewan percobaan diberi larutan glukosa sebanyak $2 \mathrm{~g} / \mathrm{KgBB}$. Mencit yang akan diberi perlakuan dipuasakan terlebih dahulu selama 18-24 jam, dengan tujuan agar sistem atau saluran pencernaannya kosong sehingga tidak akan mempengaruhi absorpsi obat.

Mencit diperiksa kadar glukosa darah awal sebelum pemberian sediaan, Untuk kelompok perlakuan 4, 5 dan 6 masing-masing diberi infusa batang gelagah dengan volume pemberian $1 \%$ dari berat badan hewan percobaan dengan konsentrasi masing-masing adalah $10 \%, 20 \%$ dan $30 \%$, untuk kelompok kontrol positif diberikan metformin dengan dosis $1,3 \mathrm{mg} / 20 \mathrm{gBB}$ dengan volume pemberian $1 \%$ dari berat badan hewan percobaan, kelompok kontrol negatif hanya diberikan larutan akuades dengan volume 1\% BB. Setelah 30 menit, kelompok kontrol positif, kelompok kontrol pembanding dan kelompok perlakuan infusa dibebankan dengan larutan glukosa yang diberikan secara oral sebanyak $2 \mathrm{~g} / \mathrm{KgBB}$ mencit dengan volume pemberian $1 \%$ BB. Setelah itu diukur kadar glukosa darah dengan alat glukometer dan strip test pada selang waktu 30 menit selama 3 jam.

\section{Pengukuran kadar glukosa darah hewan percobaan}

Mencit yang telah diberikan perlakuan sediaan uji per oral kemudian dibebankan larutan glukosa sebesar $2 \mathrm{~g} / \mathrm{KgBB}$ dan segera diperiksa kadar glukosa darah mencit pada menit awal 30, 60, 90, 120, 150 dan 180.

Cara pengukuran kadar glukosa darah mencit menggunakan alat glukometer:

1. Sebelum pemeriksaan kadar glukosa darah, mencit dipuasakan selama 20 jam. Pemeriksaan kadar glukosa darah melalui pengambilan cuplikan darah dari vena di ekor mencit dengan cara menyayat sedikit bagian ekor mencit.

2. Tetesan darah diperiksa dengan menggunakan alat glukometer. Strip tes yang telah ditetesi darah dimasukkan ke alat pemeriksa, kemudian hasilnya dibaca pada layar dalam waktu 10 detik. Nilai yang tertera pada layar merupakan konsentrasi glukosa darah dalam $\mathrm{mg} / \mathrm{dL}$.

\section{Analisa data}

Untuk analisa data dilakukan dengan mengukur perubahan kadar glukosa dalam darah pada menit awal, $30,60,90,120,150$ dan 180 dari masing-masing kelompok setelah hewan uji mengalami diabetes dengan metoda analisa ANOVA dua arah menggunakan software SPSS 21.0 for windows.

\section{HASIL DAN PEMBAHASAN}

Penelitian ini dilakukan untuk melihat pengaruh pemberian infusa batang gelagah (Saccharum spontaneum L.) terhadap kadar glukosa darah mencit putih (Mus musculus L.) jantan yang diinduksi glukosa dengan metode Tes Toleransi Glukosa Oral (TTGO), Batang gelagah (Saccharum spontaneum L.) yang digunakan sebagai sampel pada penelitian ini diperoleh dari tepi sungai Batang Sosah di Desa Sungai Kumango, Kecamatan Tambusai, Kabupaten Rokan Hulu. Batang gelagah yang digunakan sebagai sampel adalah batang yang masih muda, berwarna hijau dan memiliki ukuran tinggi tidak lebih dari 2 meter karena masyarakat Desa Sungai Kumango dan sekitarnya menggunakan batang gelagah ini secara tradisional sebagai salah satu obat untuk mengatasi diabetes. Selain itu tumbuhan ini juga mudah diperoleh karena tumbuh subur di sepanjang tepi sungai.

Pada tahap awal penelitian dilakukan identifikasi tumbuhan di Laboratorium Botani Fakultas Matematika dan Ilmu Pengetahuan Alam (FMIPA) jurusan Biologi Universitas Riau. Berdasarkan hasil identifikasi yang diperoleh, dinyatakan bahwa tumbuhan tersebut adalah tumbuhan gelagah dengan nama spesies (Saccharum spontaneum L.) yang termasuk marga Saccharum. Selanjutnya dilakukan uji skrining fitokimia sampel segar dan infusa batang gelagah. Berdasarkan skrining fitokimia yang dilakukan menunjukkan bahwa batang gelagah segar mengandung senyawa metabolit sekunder alkaloid, flavonoid dan terpenoid. Sedangkan infusa batang gelagah mengandung metabolit sekunder alkaloid dan flavonoid.

Hewan percobaan yang digunakan dalam penelitian ini adalah mencit putih (Mus musculus L.) jantan. Pemilihan hewan percobaan ini karena mencit putih jantan mudah penanganannya, relatif murah dan tidak mengalami masa estrus yang dapat menyebabkan peningkatan kadar glukosa darah (Nugroho, 2006). Mencit yang digunakan untuk penelitian adalah mencit yang belum pernah diperlakukan terhadap obat dan mencit yang dinyatakan sehat dengan kriteria tidak 
memiliki kondisi cacat secara fisik dan secara visual memperlihatkan perilaku yang normal. Untuk mengurangi penyimpangan hasil penelitian, maka dipilih mencit dengan jenis kelamin jantan, usia 2-3 bulan dan berat badan yang relatif sama antara 20-30 gram dan tidak mengalami perubahan berat badan \pm $10 \%$ selama aklimatisasi. Tujuan dilakukan aklimatisasi yaitu agar mencit terbiasa dengan lingkungan penelitian dan tidak stres. Selama aklimatisasi berat badan mencit dikontrol dengan cara ditimbang secara berkala (Ridwan, 2013).

Setelah mencit diaklimatisasi dan memenuhi persyaratan, mencit dipuasakan selama 20 jam sebelum dilakukan penelitian, tujuannya agar sistem atau saluran pencernaan hewan uji kosong sehingga tidak akan mempengaruhi absorpsi obat. Selanjutnya mencit dikelompokkan menjadi 6 kelompok percobaan, dimana setiap kelompok terdiri dari 5 ekor mencit dan selisih berat badan mencit dalam satu kelompok tidak boleh lebih dari 20\%. Kelompok 1 sebagai kontrol negatif diberikan akuades, kelompok 2 sebagai kontrol pembanding diberikan larutan glukosa $2 \mathrm{~g} / \mathrm{KgBB}$, kelompok 3 sebagai kontrol positif diberikan larutan metformin dengan konsentrasi $65 \mathrm{mg} / \mathrm{KgBB}$, kelompok 4, 5 dan 6 sebagai kelompok perlakuan diberikan infusa batang gelagah dengan konsentrasi 10\%, 20\% dan $30 \%$ secara oral dengan volume pemberian $1 \%$ BB mencit.

Dalam penelitian ini digunakan metformin sebagai kontrol positif. Metformin merupakan obat antidibetes oral golongan biguanid yang bekerja dengan mengaktifkan enzim AMP-activated protein kinase (AMPK) sehingga menurunkan produksi glukosa di hati, menurunkan penyerapan glukosa oleh usus dan meningkatkan sensitifitas insulin. Senyawasenyawa obat golongan ini tidak merangsang sekresi insulin, dan jarang menyebabkan hipoglikemia (Dipiro et al., 2015). Pada pembuatan larutan metformin dilarutkan dengan akuades karena menurut Depkes RI tahun 1995, metformin mudah larut dalam air yaitu 1 bagian zat larut dalam 1 sampai 10 bagian pelarut.

Sebelum mencit diberikan perlakuan dengan sediaan uji, diukur kadar glukosa darah awalnya terlebih dahulu. Setelah itu diberikan sediaan uji secara oral dengan volume pemberian $1 \%$ BB mencit. 30 menit setelah perlakuan, mencit diberikan glukosa $2 \mathrm{~g} / \mathrm{KgBB}$ dengan volume sebanyak $1 \%$ BB mencit secara oral sebagai penginduksi. Hewan uji diinduksi glukosa untuk melihat pengaruh terhadap toleransi glukosa tanpa merusak pankreas, sehingga hewan uji tidak beresiko mati selama penelitian (Liang et al., 2004). Metode ini merupakan metode Tes Toleransi Glukosa Oral (TTGO). TTGO adalah tes yang mengukur kadar glukosa darah dua jam sebelum atau sesudah mengkonsumsi glukosa 75 gram yang dilarutkan dalam $250 \mathrm{ml}$ air (Perkeni, 2015). Metode ini digunakan karena dapat menyebabkan kenaikan glukosa darah dengan cepat setelah penginduksian glukosa secara oral. Pada penelitian ini digunakan dosis penginduksi glukosa pada mencit sebesar
2g/KgBB (Rahayuningsih \& Amelia, 2015). Pengamatan dilakukan selama 3 jam dengan tujuan untuk mengetahui dan melihat efek penurunan kadar glukosa darah mencit pada selang waktu 30 menit dan diharapkan absorpsi glukosa darah ke dalam jaringan teramati dengan baik.

Berdasarkan hasil analisa deskriptif Two Way ANOVA yang dilanjutkan dengan uji Post Hoc Tuckey menyatakan bahwa kelompok perlakuan infusa pada konsentrasi $10 \%$, 20\% dan $30 \%$ berbeda signifikan dengan kelompok kontrol negatif yang hanya diberikan akuades dan dengan kelompok kontrol pembanding yang hanya diberikan glukosa $2 \mathrm{~g} / \mathrm{KgBB}$, sedangkan dengan kelompok kontrol positif yang diberikan larutan metformin tidak berbeda signifikan yang artinya pada konsentrasi tersebut infusa batang gelagah dapat menurunkan kadar glukosa darah mencit sama efektifnya dengan kontrol positif. Berdasarkan hasil penelitian diketahui bahwa perbedaan waktu juga mempengaruhi proses meningkat ataupun menurunnya kadar glukosa darah mencit.

Menurunnya kadar glukosa darah mencit dapat disebabkan karena adanya kandungan senyawa alkaloid dan flavonoid pada infusa batang gelagah. Alkaloid bekerja dengan menstimulasi hipotalamus untuk meningkatkan sekresi Growth Hormone Releasing Hormone (GHRH), sehingga sekresi Growth Hormone (GH) pada hipofise meningkat. Kadar GH yang tinggi akan menstimulasi hati untuk mensekresikan Insulinlike Growth Factor-1 (IGF-1). IGF-1 mempunyai efek menurunkan glukoneogenesis sehingga kadar glukosa darah menurun (Bunting et al., 2006). Senyawa flavonoid meregenerasi sel $\beta$ pankreas dan mampu merangsang sekresi insulin (Dheer \& Bhatnagar, 2010). Flavonoid dapat menurunkan kadar glukosa darah dengan kemampuannya sebagai zat antioksidan. Flavonoid bersifat protektif terhadap kerusakan sel $\beta$ sebagai penghasil insulin serta dapat meningkatkan sensitivitas insulin. Mekanisme lain adalah kemampuan flavonoid dalam menghambat GLUT 2 mukosa usus sehingga dapat menurunkan absorbsi glukosa. Hal ini menyebabkan pengurangan penyerapan glukosa dan fruktosa dari usus sehingga kadar glukosa darah turun. Flavonoid juga dapat menghambat fosfodiesterase sehingga meningkatkan adenosin monofosfat siklik (cAMP) pada sel $\beta$ pankreas. Peningkatan cAMP akan menstimulasi pengeluaran protein kinase A (PKA) yang merangsang sekresi insulin semakin meningkat (Song et al., 2002).

\section{KESIMPULAN}

Berdasarkan hasil pengujian pada pemberian infusa batang gelagah (Saccharum spontaneum L.) pada konsentrasi $10 \%$, 20\%, dan $30 \%$ berbeda signifikan dengan kelompok kontrol negatif dan kelompok kontrol pembanding ditandai dengan $\mathrm{p}<0,05$ sehingga dapat menurunkan glukosa darah pada mencit putih (Mus musculus L) jantan yang diinduksi glukosa secara oral . 


\section{DAFTAR PUSTAKA}

Bunting, K., Wang, J. \& Shannon, M.F. 2006. Control of Interleukin2 Gene Transcription: A Paradigm for Inducible, TissueSpecific Gene Expression. Canberra: Elsevier Academic Press.

Depkes RI 1995. Farmakope Indonesia. Edisi ke-IV. Jakarta: Departemen Kesehatan Republik Indonesia.

Depkes RI 2005. Pharmaceutical care untuk Penyakit Diabetes Melitus. Jakarta: Departemen Kesehatan Republik Indonesia.

Devi, J.A.I. \& Muthu, K. 2014. Phytochemical Screening, Antioxidant Activities and Total Phenolic Content of Ethanolic Extract from Whole Plant of Saccharum spontaneum (Linn.). International Journal of Chemical and Pharmaceutical Sciences, 5(2): 112-118

Dheer, R. \& Bhatnagar, P. 2010. A Study of The Antidiabetic Activity of Barleria Prionitis Linn. Indian Journal of Pharmacology, 42(2): 70-73.

Dipiro, J.T., Talbert, R.L., Yee, G.C., Matzke, G.R., Wells, B.G. \& Posey, L.M. 2015. Pharmacotherapy:A Pathophysiologic Approach, 10th edition. New York: Mc Graw Hill.

Harborne, J.. 1987. Metode Kimia Cara Modern Menganalisis Tumbuhan. Bandung: ITB.

Hidayatullah, M. \& Mora, E. 2018. Uji Aktivitas Antioksidan Ekstrak Etanol Batang Gelagah (Saccharum spontaneum L) dengan Metode DPPH (2,2-diphenyl-1-picrylhydrazyl). Jurnal Penelitian Farmasi Indonesia, 1(1): 1-5.

Kemenkes RI 2018. Riset Kesehatan Dasar (RISKESDAS). Badan Penelitian dan Pengembangan Kesehatan Kementerian RI Tahun 2018.

Lapuz, A., Arabiran, R., Sembrano, T., Albaniel, J., Paet, J. \& Maini, H. 2016. Preformulation and Evaluation of Antibacterial and Anti-Inflammatory Activities of Saccharum spontaneum Linne Root Extract Cream. International Journal of Chemical Engineering and Applications, 7(3): 204-208.

Liang, Y., Osborne, M.C., Monia, B.P., Bhanot, S., Gaarde, W.A., Reed, C., She, P., Jetton, T.L. \& Demarest, K.T. 2004. Reduction in Glucagon Receptor Expression by an Antisense Oligonucleotide Ameliorates Diabetic Syndrome in $\mathrm{db} / \mathrm{db}$ Mice. Image (Rochester, N.Y.), 53: 367-374.

Norcahyati 2012. Tumbuhan Berkhasiat Obat Etnis Asli Kalimantan. Samboja: Kementrian Kehutanan.

Nugroho, A.E. 2006. Animal Models of Diabetes Mellitus: Pathology and Mechanism of Some Diabetogenics. Biodiversitas, Journal of Biological Diversity, 7(4): 378-382.

Perkeni 2015. Konsensus Pengelolaan dan Pencegahan Diabetes Melitus Tipe 2 Di Indonesia 2015. Jakarta: Pengurus Besar Perkumpulan Endokrinologi Indonesia.

Rahayuningsih, N. \& Amelia, S. 2015. Uji Aktivitas Antidiabetes Infusa Daun Pohpohan (Pilea trinervia Wight.) Pada Mencit Putih Jantan Galur Swiss webster. Jurnal Kesehatan Bakti Tunas Husada, 13(1).

Ridwan, E. 2013. Etika Pemanfaatan Hewan Percobaan Dalam Penelitian Kesehatan. J indon Med Assoc, 63(3).

Ripa, F.A., Haque, M. \& Haque, M.I.U. 2009. In vitro Antimicrobial, Cytotoxic and Antioxidant Activity of Flower Extract of Saccharum spontaneum Linn. European Journal of Scientific Research, 30(3): 478-483.

Song, J., Kwon, O., Chen, S., Daruwala, R., Eck, P., Park, J.B. \& Levine, M. 2002. Flavonoid inhibition of SVCT1 and GLUT2, Intestinal Trasporters for Vitamin $\mathrm{C}$ and Glucose. J.Biol, 1: 303-315.

Tag, H., Kalita, P., Dwivedi, P., Das, A.K. \& Namsa, N.D. 2012. Herbal medicines used in the treatment of diabetes mellitus in
Arunachal Himalaya, northeast, India. Journal of Ethnopharmacology, 141(3): 786-795.

Wijayakusuma, H. 1995. Tanaman Berkhasiat Obat di Indonesia Jilid II. Jakarta: Pustaka Kartini. 